\title{
Improving Governance in Developing Countries, Especially in Fragile States
}

\author{
Dennis de Tray
}

\begin{abstract}
The world is increasingly aware that climate change could eventually destroy the earth as we know it - but over decades if not centuries. Fragile states - the poorest and weakest developing countries - should be of the same order of concern to the international community as global warming, and their downside is likely to be much more immediate. Fragility cost the world more than USD 13 trillion in 2015 [1], and research suggests that fragility is predicted to get worse in the coming decade (op. cit.), underscoring that the international development community needs to rethink the way it works in fragile states. This paper contributes to this rethinking by analyzing why the international community performs badly in fragile states and showing how it could do better through two case studies.

The paper is in two parts. It begins with an overview of fragility, its causes and consequences, and why the international community has a poor track record in reducing fragility. In the second part, the paper turns to two case studies, of East Timor and of Afghanistan, to show how the principles set out in the first section can be applied on the ground and in detail.
\end{abstract}

Key words - Counterinsurgency, fragile states, governance, international development.

\section{SOURCES OF FragiLITY}

The term "fragile states" originally came into vogue in the mid-1990s [2]. Fragility has many roots - poor governance, corruption, ethnic and religious tensions, external factors. But all these sources produce one common characteristic: the people of fragile states do not see their governments delivering even the most basic of public goods. As a consequence, they see no point in supporting the government.

While the literature identifies many fragility sources, most fragile states have at least one common feature: they lack functioning national governments - working levels of governance. Fragile-state national governments are either too weak to serve their people or too corrupt - often both.

Poor governance creates a vacuum in fragile states that insurgents, international terrorists, and criminal gangs quickly fill. de Tray [3]. reviews how the military recognizes the role of improving governance in defeating insurgencies. The Army's Counterinsurgency Manual, written by David Petraeus [4]. cites a French soldier-scholar David Galula [5]. Galula was an early proponent of the notion that military might alone will not overcome an insurgency. Instead, defeating an insurgency requires a "political solution," Army talk for improved governance and strengthening the relationship between a people and their government.

Suppose one pushes this argument back one stage: if the international community was more effective at improving governance in pre-conflict fragile states, strengthening the link between a people and their government. Then, the world would likely face less fragility and fewer negative spillovers from fragility.

The international community's current approach to development and improving a country's governance is a topdown approach. Usually, it starts with a country's central Government. Then, it tries to entice the Government to improve policies and governance by offering large amounts of conditioned development assistance, hoping that any improvement in central-government governance will cascade down to lower government levels.

Some international projects focus on local governments, but these are exceptions, not the rule. As anyone with experience in development will recognize, central governments are too often more focused on rent-seeking (corruption) and donor management than serving their people.

Central governments are also frequently out of touch with their people - an issue not limited to developing countries, as the recent US, the UK, and Europe events have shown.

\section{THE INTERNATIONAL COMMUNITY'S RECORD IN FRAGILE STATES}

The International Development community comprises two related but distinct elements: bilateral aid programs that individual governments finance and managed and multilateral organizations (the UN, the World Bank, and many others) that are "owned" and financed jointly by many countries.

Neither of these organizations is free from political influence, which leads to financiers' interest influencing the nature of assistance and conditionality. Still, the multilaterals are probably slightly better on that front than bilateral agencies.

In terms of broad trends, Fig. 1 shows changes in fragility from 2010 to 2020, courtesy of the Fund for Peace.

As the map shows, precious few countries improved between 2010 and 2020 (the black areas on the map). These trends imply that "more of the same, but this time we are serious" is unlikely to improve the international community's track record in fragile states. 


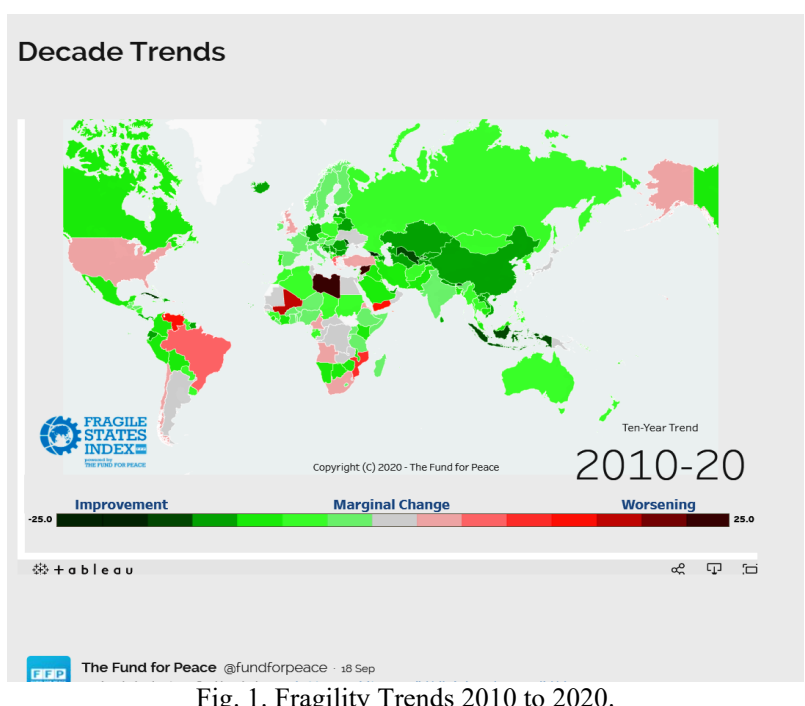

Fig. 1. Fragility Trends 2010 to 2020.

\section{PARSING InTERNATIONAL DEVELOPMENT}

Why has the international community been ineffective in improving governance in fragile states? International development assistance can have one of at least two objectives: the international community can seek to increase peoples' well-being in developing countries: international welfare. Or it can try to increase the capacity of developing countries to serve their people, capacity building. While related, these are two distinct objectives requiring different approaches.

For the first objective, international welfare, the international community is the one building roads, schools, health clinics, etc. These activities are what most development agencies mainly do - large complex projects which mandate donor design, donor funding, and donor oversight. With donors' extensive financial and personnel resources doing all the work, national governments are sidelined and free to sit back and seek rents.

The advantage of the current donor approach is that it has led to substantial increases in human welfare, increased life expectancy, better health, higher literacy over the past five decades [6], [7]. However, it has not had similar successes on the capacity-building front.

This difference in results between international welfare and capacity building explains why Radelet and Kenny, William Easterly, author of White Man's Burden [8], and Dambisa Moyo, author of Dead Aid [9] is all correct, even though they appear to be on opposite sides of the aid effectiveness debate. This is possible because Radelet and Kenny document the successful results of international welfare, while Easterly and Moyo focus on capacity building - or the lack thereof in developing countries.

Capacity building is a longer-term objective that requires giving national authorities responsibility - letting national governments do development, not the international community, even if the international community is providing the finances. At the base of this view is the notion that countries need incentives to improve capacity, which requires donors to step back. Stepping back may not be possible for large national projects, but there is evidence that it will be for community improvement projects. These statements are nowhere more valid than for fragile states.

I now want to turn from the general to two specific case studies, East Timor and then Afghanistan. The following section summarizes a note [10] I prepared following a Dili, East Timur consultancy in 2008.

\section{DILI JUNE 2008}

In post-conflict states, the weakest link in the chain that secures these countries to a stable future is the relationship between people and their government. Fragile states often come out of conflict episodes with broken bonds between citizens and governments. Thus, a first step on the statebuilding road must create a connection between a people and their government.

A conflict immediately arises - these countries have massive immediate welfare needs, housing, food, water, health and education, transportation infrastructure. However, when donors fill them, it signals that governments either cannot or do not want to - a bad start for any government when it wants to connect with citizens.

Collier [11] shows that the come out of conflict frequently return to conflict. Why? No one, especially the youth, sees no reason to wait. No reason to be patient, no reason not to return to violence. If a post-conflict country is to focus on development, its people must see their government functioning. The international community needs are to help nurture this critical relationship but what they often do produces the opposite result.

As I argue below, a combination of wrong incentives, wrong institutional models, wrong time frames, and wrong capacity problem means that donors are in the capacity stripping business. This capacity stripping is the worst in countries that can least afford it - Fragile states and postconflict countries.

Following background on Timor, I outline the seven-point plan I developed for East Timor. A plan that would redirect its development program to serve its people and accelerate connecting its citizens with their government.

\section{A Brief History of a SMall COUntry}

Timor-Leste, as shown in Fig. 2, a small country, with less than a million people, had a difficult start in life. It was occupied for well over 500 years: by the Portuguese (450 years), by the Japanese during the Second World War, by the Indonesians (24 years). It became an independent country only in 2002. These long occupations alone made forming a new government a significant challenge, but there was more.

For reasons likely of arrogance, Indonesia was deeply surprised and disappointed when a decisive majority of Timorese vote for separation from Indonesia in 1999 (more than 80 percent of the population voted for independence). In response, pro-Indonesian militia launched a scorched earth retribution policy. During this campaign, Indonesian armed forces destroyed almost all of Timor's already meager infrastructure of any consequence; they killed 2000 people and left two-thirds of the population homeless. 


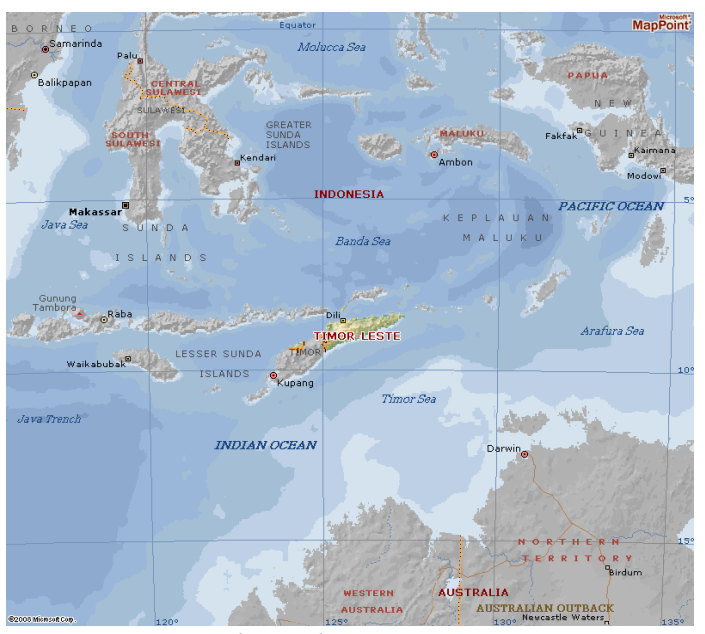

Fig. 2. Timor Leste.

Since independence, Timor-Leste has finally had a turn of luck. The country, with the help of Australia, discovered oil and gas in the Timor Sea. This discovery was jointly developed with Australia's assistance, yielding, in 2008, significant profits that could have supported a substantial home-financed development program. In 2008, Timor-Leste saved rather than spent its oil money. In March 2009, it had accumulated more than $\$ 5$ billion in its Petroleum Fund. The equivalent of $\$ 5000$ for every man, woman, and child, more in per-capita terms than the oil funds held by Azerbaijan, Kazakhstan, or Russia. The international community lauded East Timor's government of its management or its oil revenues. Saving oil profits seemed to make sense in light of East Timor's capacity constraints, but not given its development and infrastructure needs. No country as poor as Timor-Leste should be on a public sector saving binge. Countries with extensive development do not need a fat saving account. They so need the capacity to spend well.

As oil revenues rolled in, East Timor, as in Fig. 3, found itself bereft of the capacity to spend it. A starting capacity constraint was the fact that half the population was unable to read or write. In 2008, the UN Human Development Report listed only 16 countries globally with literacy rates lower than East Timor's. In addition, only about two-thirds of primaryaged children attend school, down from nearly three-quarters at the time of independence. These low education standards spilled over into the government. Thirty Ministry of Finance employees at grades 3 and 4 (the government system has 7grade levels) recently tested at a third-grade average math proficiency. Third-grade math proficiency in the Ministry of Finance! Imagine what numeracy was like in the rest of the government. While I was in Dili, I met an IMF budget preparation trainer. She said that only $20 \%$ of her trainees understood fractions, decimals, or percentages.

Timor-Leste's languages were also a problem; The country had two official languages, Portuguese, and Tetum. Portuguese was the language of legislation and the courts. Yet less than $10 \%$ of the population spoke or understood it.

Senior government officials may speak Portuguese but may not speak Tetum, Timor-Leste's local language. Many mid-level government officials were more comfortable in Bahasa Indonesian than Tetum or Portuguese due to their Indonesian occupation and its reliance on Indonesian universities for its higher education needs.

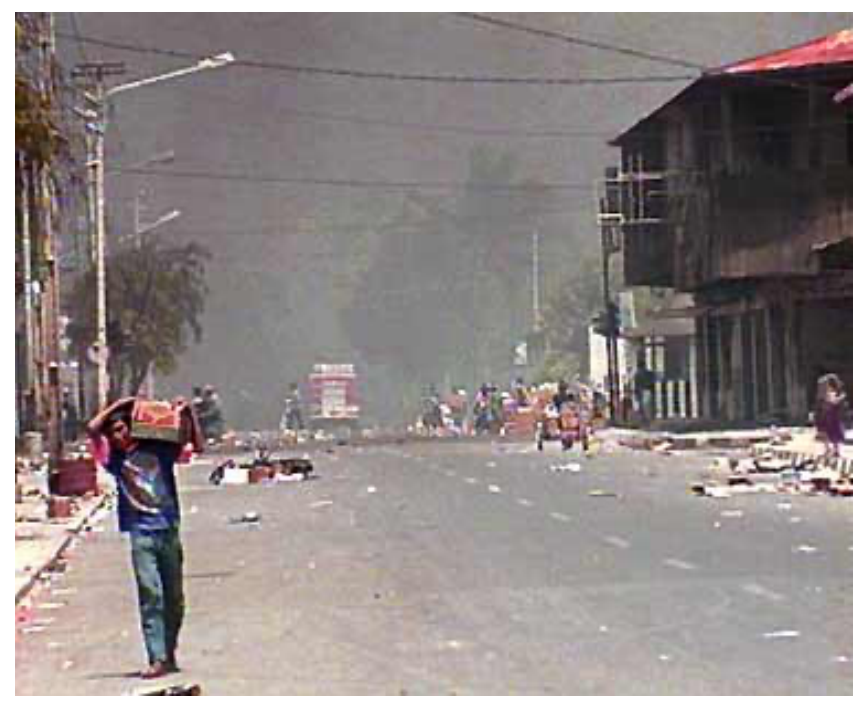

Fig. 3. Dili, 2008.

With these skills deficits, where do you start? Unfortunately, donors started by buying off the country's limited capacity.

There were 17 donors active in Dili in 2008, AusAID, the largest in terms of money and personnel on the ground. Most of the army of advisors and consultants that donors supported spoke no Tetum, Portuguese, or Bahasa Indonesia. To function, they needed multilingual Timorese counterparts, which meant they ended up hiring most of the Timorese who could speak English or Portuguese, were competent, and who could work in an international environment, precisely the people the government needed to execute its development programs.

A 2008 inventory found 365 donor-supported advisors and consultants at work in Timor-Leste government offices, of which roughly 250 were residents in Dili.

The resulting competition among donor agencies and embassies for qualified, multilingual Timorese pushed wages for qualified Timorese nationals in the international sector far above what the government could pay (five to ten times government salaries). Even drivers in the UN system earned considerably more than government officials.

This hiring by donors of qualified locals put the Government in a difficult position. The government had to deliver and do so quickly to gain legitimacy in the people's minds, but the donors had removed from the labor force the very people it needed to do that. Moreover, if the Government turned to donors to deliver, the people would see it as incompetent; if the Government tried to deliver on its own, capacity constraints would likely doom its efforts, with the same result - no gain in faith in the population.

Donor-demand for local talent has the worst effect on governments in countries where capacity is weakest, where governments are most desperate for a few qualified people in key positions.

Why do donors in the capacity-building business often end up making things worse? Why does much of what donors do in fragile states end up making the government capacity problem worse, not better? Below, I look more closely at the four reasons I mentioned above: wrong incentives, wrong models; wrong time frames; and wrong capacity problem. 


\section{The Wrong INCENTIVES}

Donors do not work for poor countries. Donors are accountable to and therefore work for rich country governments and the taxpayers who support those governments. Their natural bureaucratic instinct is one of survival. To survive financially, they want to keep their rich country-masters happy. Donors are in service to poor countries, but accountable to and financed by rich countries creates incentives that often produce programs that neither satisfy paymasters nor help poor countries. We've known about these perverse and confusing incentives for a long time [12].

For aid agencies to compete for tight fiscal resources, those agencies must garner political support in their home countries. They can try to do this by attempting to convincing taxpayers that foreign aid is in taxpayers' interest. Sometimes these arguments help, but historically they have not been enough to keep development agencies competitive for annual financing.

Government agencies need friends outside the Government; donor agencies are not an exception. Aid agency friends and supporters can be categorized under the following headings, (1) the consultant industry, (2) contractors, and (3) special interest groups. The more richcountry consultants an aid agency employs (or funds others to employ), the more contracts it gives its home country firms, the more political support that aid agency gets. Similarly, the more aid programs focus on issues at the top of special interest agendas, the more political support.

Unfortunately, as Timor-Leste shows, these incentives work in precisely the wrong direction regarding the needs of fragile states.

The distorting effects of donor agendas are there to be seen. For example, in Dili, I organized a meeting to discuss ideas on the capacity problem as in Fig. 4. A youngish gentleman from a donor country comes in a few minutes late. He sits down and then announces that he is an expert in ethics and has come to Dili to teach Timor-Leste's government workers "values." Putting aside the paternalism of the statement, I asked whether the time was right for the Government to concern itself with an ephemeral and long-term set of issues. He replied: "... 'merit' and 'accountability' are universal human values! On my way back to my office, I walk past burned-out buildings, roads full of potholes, and the remains of the IDP (internally displaced people) camps, I was mystified by the man's agenda. By the way, his country of origin is among the more progressive donor countries.

Donors also need visibility if they are seen as valuable by those who support them financially. Taxpayers and aid advocates ask, "what have you done for me today?" While this "show the flag" syndrome is understandable, it is also highly counterproductive. Donors end up claiming success for development outcomes when the people need to see their government as successful.

Given the incentives they face, it's easy to understand why donors react the way they do. But that the fact remains that their actions undermine the first essential step on the road to a functioning state, strengthening government credibility.

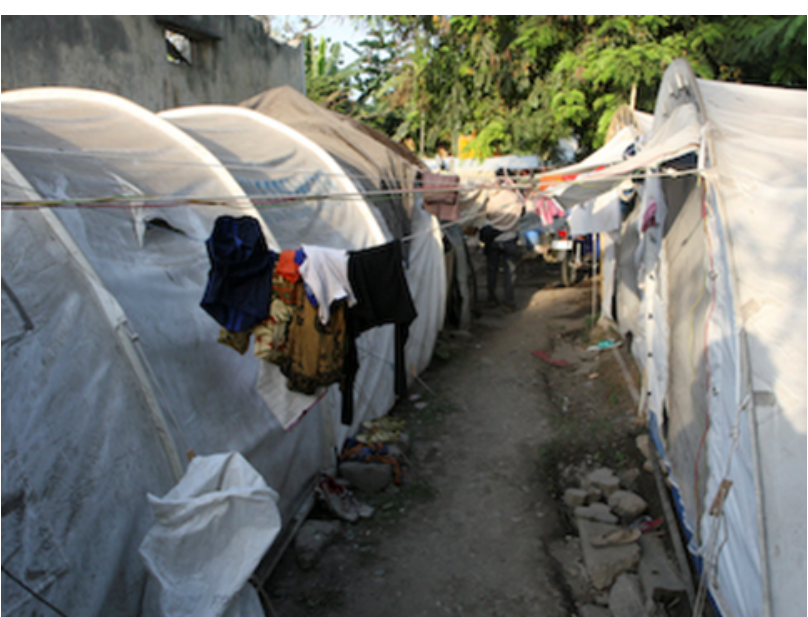

Fig. 4. Dili, 2008.

\section{The Wrong Models}

The Prime Minister tasked an Australian consultant to create a civil-service commission. When I read the draft proposal, I found that he based his suggested approach on several commissions set up in Australia. I tell him that the idea that a civil service commission modeled after successful efforts in the Australian provinces of Victoria and Tasmania will work in Dili seems to me highly unlikely. While he agrees with my concern, he also asks, if not this, what can he do?

The international donor community undermines capacitybuilding in fragile states by promoting rich country models much too complex for weak countries. They then exacerbate this problem by overwhelming governments with technical assistance. Both overfly complex institutional models and too much technical assistance result from the incentive issues I mention above. When a poor, new country needs help, the international community rushes in with rich country agendas and priorities - good governance, gender equality, fighting corruption, human rights.

Rory Stewart has this observation on the Coalition plan in Iraq, based on his time as Deputy CPA (Coalition Provincial Authority) Governor in Maysan Province, Iraq "The CPA in the Green Zone wanted to build the new state in a single frenzy. So instead of beginning with security and basic needs and attempting the more complex things later, we simultaneously implemented programs on human rights, the free market, feminism, federalism, and constitutional reform. We acted as though there could be no tensions between the different programs, no necessity to think about sequencing or timing." [13].

To make matters worse, when donors start working in a country just out of conflict, in their haste, they rely on advisors and consultants from their donor countries when they begin to create institutions designed to build capacity. These cadres end up not filling capacity shortfalls but making them worse. The foreign consultants use up government time. Decision-making in fragile states is usually concentrated at senior levels meaning that consultants and advisors feel they have to speak to the top tier of government officials using up what little capacity the government has in endless meetings.

To deliver today, governments do need delivery capacity, but that challenge is not the capacity problem on which donors tend to focus. Even in the face of decades of evidence 
suggesting otherwise, donors continue to act as if fragile state institutions can be built quickly and by outsiders. Lant Pritchett and Michael Woolcock call this assumption the "Denmark" syndrome [14]. "Denmark" is their shorthand for a development world in which the transfer of developedcountry institutions (for example, the institutions of Denmark) to poor countries would somehow turn them into developed countries overnight. Development history contains numerous examples of institutional reform programs that failed. Yet, Donors continue to act on the assumption that donors can build rich northern-country institutions in poor southern countries quickly and from the outside by copying western institutions.

\section{The Wrong Time Frames}

One critical lesson from development assistance over the past half-century is that capacity-building takes time, a minimum of years, more often decades, many times, generations. This requirement for a lengthy period to build sustainable capacity is especially true in post-conflict settings. Governments in countries recently out of conflict have to be built from scratch. The existing Government gained its experience under conditions that have little to do with running a country in peacetime. To make capacity matters worse, conflicts tend to take a hefty toll on local technical expertise. Collier [11] underscores that capacity building in post-conflict states is especially difficult. In terms of lessons, failed institution-building efforts tell us little or nothing about the length of time needed to produce a functioning institution.

Chile, in contrast, offers a helpful study in a rare capacitybuilding success. The Chilian example gives a sense of the time that it takes to produce successful capacity building. Chile's judiciary, before 1990, was known domestically and internationally for corruption - its high court and trial judges were known more for selling sentences - than for delivering justice. Chile was at that time an advanced middle-income developing country. Chile started its judicial reforms in 1990, with the creation of a Judicial Academy created to control the recruitment of judges and their career path. Chile reformed the judicial system more widely by eliminating activities that served as a basis for corruption.

These reforms made Chile a star in Transparency International's Corruption Perceptions Index, ranking that country first in Latin America, on a par with the United States, and right behind France and Belgium internationally. Quite extraordinary for a Latin American country. But even with the considerable progress Chile made and the international recognition it received, a 2006 report by the Chilean government concluded that there was still "much to be done." This conclusion came after fifteen years of effort by a highly competent civil service in a stable and democratic state. If fifteen years was not enough for Chile, how long should building a reasonable legal system take in in states as poorly resourced in people and money as fragile states? The answer would seem to be decades, not years.

\section{The Wrong Capacity Problem}

These factors, wrong incentives, models, and time frames have led donors to try and fix a capacity problem, but the wrong capacity problem. To identify the correct capacity constraint, donors need to ask what both governments and donors should be doing in fragile and post-conflict states that is complementary, not engage in a competition for acknowledgment. After the fighting stops, poor countries face an immediate need for humanitarian assistance. Much of the population will not have enough to eat, and many will not have housing; there will be a lack of accessible primary medical care. Often international donors and NGOs successfully step in at this juncture.

With time, these countries reach a point when security and stability reach a point that allows for implementing traditional long-term development agendas. Filling these agendas has been aid agencies' core business, which appears to make sense.

However, it is essential to recognize a period between humanitarian assistance and long-term development programs when countries face political instability, driven by weak government capacity and an impatient and demanding population. This interim period is neither humanitarian assistance nor standard aid agency fare. It is a period critical to fragile states' futures, yet one for which we haven't had good intervention models. It is challenging for donors because they face finding programs that will get services and jobs flowing through government programs, not donor programs.

With the assistance of donors and others (I get to these others below), the programs that governments need to put in place in this in-between period have to meet the following criterion. First, citizens need to have roofs over their families' heads. Second, they need to have a job and travel to their jobs safely jobs, and they need to know that their government works for them by seeing progress in their communities fixed roads, access to water, and electricity, to name three. Provincial, district, and community levels of government deliver most of these outcomes. But, most externally financed capacity-building occurs in capitals or major cities. This mismatch is how donors focus on the wrong capacity problem.

One solution to this problem is the provincialreconstruction team models that the U.S. Army tried in Afghanistan and Iraq 9see below). Not these exact models, but the main principle behind them: getting central governments to function is a long-term goal, not suited for a state just out of conflict or a fragile state. Donors feel under tremendous pressure to get jobs and services flowing throughout a country quickly to signal that the Government is starting to work. In doing so, donors frequently feel the need to bypass weak and corrupt national governments.

The solution to this problem is recognizing that getting services to flow happens best at the lowest levels of Government. But as discussed in [3], the Provincial reconstruction model's implementation in Iraq and Afghanistan left much to be desired.

My involvement in using local governments to serve communities started in Indonesia when I was the World Bank's country director for Indonesia for five years, the last 
two during the 1990's East Asia Economic crisis. Indonesia was not and is not a fragile state. Then-president Suharto was at the peak of his power. The country was growing at a remarkable $8 \%$ a year, following 20 years of $7 \%$ growth. Even so, the World Bank felt that it had a "capacity" problem in Indonesia. Indonesia was near the top of Transparency International's list of corruption sinners. Working in Indonesia was an anathema to then World Bank President Jim Wolfensohn who had just launched his cancer of corruption campaign. Wolfensohn's evident dislike of Indonesia, especially of Suharto, made World Bank business in Indonesia tricky. So, the challenge that my team and I faced was how could serve Indonesia's poor, of which there were many, and at the same time avoid the country's corruption?

Scott Guggenheim's Village Infrastructure Project provided one answer. Scott went on to greater fame with Indonesia's Kecamatan [15]. These projects were models for many decentralized projects that emphasized delivery by subnational-province, district, community-governments. Guggenheim successfully applied his local-delivery model to Afghanistan. The World Bank tried something similar in the Kyrgyz Republic when I was the World Bank's country director for Central Asia. The common element of these projects was that they all relied on the same approach to deliver community services and infrastructure: All these projects combined civil society engagement ensuring oversight with local delivery. Thus, the role of the international community was twofold. First, to ensure the transparency, civil society needed to play its oversight role, and second to provide local technical support when needed.

These and several other projects led to the conclusion that local governments were better at delivering basic services and creating local jobs than do National governments. Central governments do not have the knowledge or reach to serve communities country-wide. The donor community is even less well placed to deliver these local services and job programs. Second, these projects strengthened people's faith in government since local governments are the face of government that most citizens see and know. When local officials serve people, citizens start to believe their governments are worth supporting. However, even though local governments have shown remarkable strength and delivery capacity on many fronts, if local governments are to expand their roles, they will need help. Centralized civil service reforms, budget execution courses, computerized management information systems, judicial training will do nothing to produce jobs and services if local governments don't function. My experience in Afghanistan led me to understand that local governments have much more capacity than they are generally given credit for, so technical assistance is not essential. The key to local government success is the deep and broad knowledge local officials have of local needs and priorities.

\section{A. From Stripping to Supporting - It Is Possible}

The sense among donors that the situation in fragile states requires immediate and massive donor interventions means that donors in fragile states overwhelm weak governments and steal their best people. If the result of these interventions were better lives for a country's people, there we might have grounds for a conversation on a national scale. But Iraq,
Afghanistan, Timor-Leste, and Liberia show, regardless of the amount of money or the number of foreign advisors and consultants' donors provide a country, results on the ground show that it is usually not enough. If a country's government does not work in the minds of the people, little happens to strengthen the foundation for long-term development, leading countries to quickly slip back into chaos. What does happen is externally driven, which further erodes people's support for their government.

The level of criticisms toward the international aid community has reached a level of complaints against the aid system, which has prompted some [9] to argue that the only good aid agency is one that does not exist. Bill Easterly has been one of the leaders of this anti-foreign-assistance movement, argues that the only way forward is a revolution that takes aid out of the hands of government bureaucrats. While Easterly is correct that the system needs repairing, the notion that the way forward is through a "revolution" seems far-fetched. Fortunately, there is another way, an approach between our current methods, and their distorting effects on government credibility, and a revolution.

In detailing this third way, we must start with the fact that none of the players in the development business-the donors, the governments, non-government organizations, civil societies-can by themselves produce lasting improvements in people's lives. Sustainable development requires a partnership involving each of them with complementary roles if countries are to develop. The separate roles are not difficult to see governments as the national entity; donors since poor countries do need financial support. NGOs and civil society because the system has to be held accountable, especially in countries with no or weak democracies.

\section{How to do Development Better}

General discussions on how donors can be more effective in fragile states are not helpful since each reader will have a different county setting in mind. To avoid unnecessary confusion in outlining how international development can work better in fragile states, I will focus on two examples; The first is East Timor. This example is a case study of what Timor-Leste needed to do in 2008 when I was active in Dili, its capital, as in Fig. 5. but these lessons apply much more broadly.

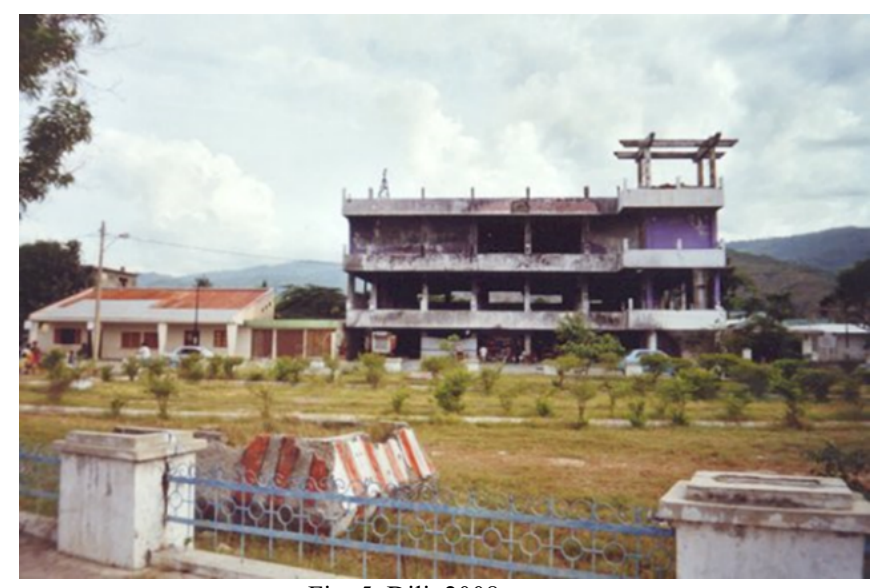

Fig. 5. Dili, 2008 
In 2008, the Timor-Leste had a badly out of balance program for development, mostly thrust on it by the donor community. There was too much investment in longer-term efforts to build institutions and create capacity when more jobs and improved infrastructure were the immediate priority. The Timorese government needed to work with its donor community to shift their portfolios away from capacity building and towards filling the country's significant and immediate needs. Donors needed to accomplish this shift needed in a way that gave the Timorese government credit for outcomes to avoid leaving the country's people with the impression that the international community was doing it all.

Doing the was a matter of getting the balance correct about donors supporting government efforts without appearing to take over.

I outline the program that my Timorese colleagues and I developed at that time to achieve this balance. It was not a program designed to thrust East Timor into middle-income status but to create the stability to build such a program by creating jobs and improving infrastructure and services. As I told then, PM Xanana Gusmão, Timorese needed to see their government at work improving their lives.

Timor was fortunate in that it had the ingredients for such a program. It had a committed set of donors, lots of technical assistance, and, most important, the money coming from newly discovered oil in the Timorese sea.

What it was missing was a program that would bring all these elements together in a workable program. Instead of using its oil revenues, likely based on donor advice and pressure, it chose to save that money. Strange behavior for a small, relatively rich country with substantial immediate development needs

Critical elements of a new program, the program had to create demand for Timorese labor at all skill levels.

In addition, it has to improved service and infrastructure using local firms.

Such a program would have five components; some would have been based on ongoing government programs. These are:

- The provision of public services;

- Repairing and building infrastructure;

- Building houses;

- A program to develop vocational skills;

- Direct support to small and medium indigenous firms.

The government could manage such a program under one of at least two umbrellas, first, Regional Service Authorities (RSA). One possible model for RSAs could be provincial reconstruction teams (PRTs) in Afghanistan and Iraq, but with oversight, facilitation, and accountability roles, not provider roles. To learn about the evolution and functions of PRTs, see chapter two of de Tray [3]. The second would be contracting out to regional firms with one proviso - payment based on performance.

Public services: street cleaning, garbage collection, beach clearing: cleaning up Timor-Leste would be the program's low-skills employment provider. The demand for such workers was great in 2008 as the state of Dili's roads and beaches were abysmal, a clear indication that neither the government's nor donors' public works programs were working.

The second element would be a slightly more skill- intensive infrastructure provision program designed to create and repair: road repairs, rehabilitating public buildings, including schools and health facilities, building, repairing, and cleaning sewer systems.

Support for private sector development would constitute the third element. The final element would be a vocational education training program to develop the skills needed for simple infrastructure projects, for example, housing (Skills in carpentry, plumbing, wiring, welding, bricklaying, concrete work, etc.).

\section{A. How to Deliver}

In The Bottom Billion [16], Paul Collier discusses the problem of improving citizens' lives in post-conflict and fragile states. He starts with the correct point that Donors cannot create government capacity to deal with the problem in the needed time frame. As a solution, Collier promotes the idea of independent service authorities (ISA). Like Provincial Reconstruction Teams, ISA would-be - providers of technical support, identifiers of funding sources, but not implementors.

Based on my later Afghanistan experience, I now do not think that ISAs are necessary. In Afghanistan, even during a war, I found that most local governments could do what communities needed without external technical support if given the resources and authority.

Suppose Timor-Leste and its donor supporters did not want to rely on local governments. If that was the case, they could have turned to an intermediate model in which regionally based ISAs ensure transparency and effective communication, but they would not implement. The provincial reconstruction teams of Afghanistan and Iraq provide examples, with some changes in composition and roles. This approach has several advantages. First, these units remain a part of the public sector in the eyes of the people of Timor-Leste, and second, salaries and staffing rules can be merit-based and competitive for diaspora and others, attracting skilled Timorese managers. But the Afghan experience showed that local governments were capable of performing these tasks without external assistance.

A contracting model would serve as an alternative approach. A contracting model, if correctly structured, would accelerate delivery in the face of limited government capacity. The contracting model is found mainly in more advanced developing countries. Under this model, the Government issues a tender open to domestic and regional private firms to deliver a predefined set of services (trash collections would be an example). Contracts would be such that payment would be issued only for services delivered, under precise quantity and quality standards. For example, under this model, the Timorese Government could issue a request for proposals to clean up Dili, where "clean up" would have well-defined and measurable outcomes.

An essential requirement would be to hire Timorese whenever and wherever possible, definitely below a management level.

In 2008, Timor-Leste had a crucial need for housing, see Fig. 6 . The government could do little else to signal better that the Timorese government was back in business than implement an effective housing program. Such a program would have built on an already existing set of programs. 
Timor-Leste already provided $\$ 4,500$ grants to IDPs (internally displaced people) who had lost their houses. An extension of the ongoing program would have the government provide income conditioned grants to all TimorLeste's poor to help them pay for housing renovation and reconstruction.

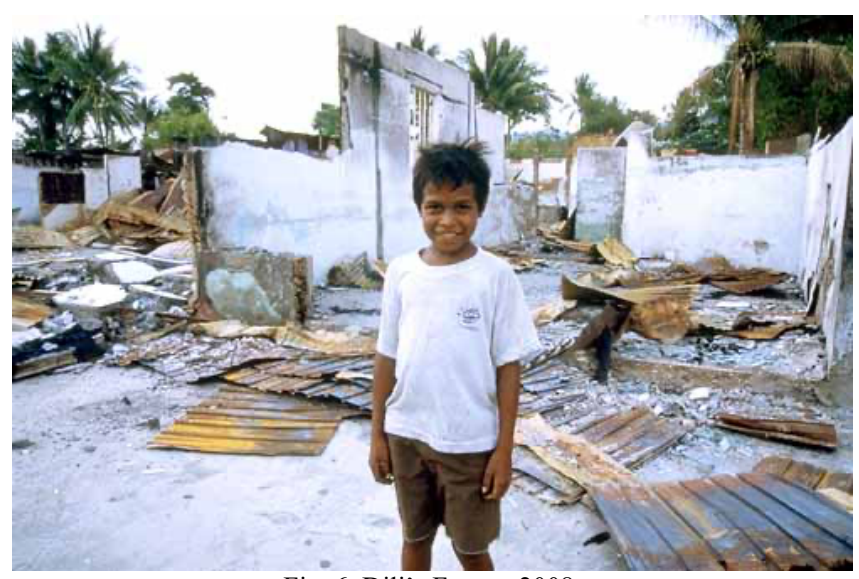

Fig. 6. Dili’s Future, 2008

It takes more than grants to get houses built. The Government would also have to find a way to support the housing construction sector. To do this, the Timorese government could turn to regional. A 2004 tsunami destroyed much of Aceh, Indonesia's housing. In response, the government of Indonesia built over 100,000 houses in a short period. The Indonesian in charge of this program. Kuntoro Mangkusubroto would have made a great advisor on Timor's program. Notably, he would have brought appropriate regional experience to Timor.

\section{B. From Ideas to Action}

In 2008, the conditions of Dili, Timor's capital, and Timor's countryside left no doubt that neither donor's nor government programs were doing what they needed to do. Even in 2020, while Dili was looking better, most of the country was still in need of significant infrastructure repairs. The problem was not a lack of will or recognition; it is implementation. With this in mind, I developed a seven-point program for moving from ideas to action and results. The model I develop there was Timor-specific, but governments and donors could apply it to other fragile states.

\section{A. Decide on a Delivery Model (or Models)}

The current government/advisor model will not start delivering for the Timorese people soon. But, regardless of the approach selected (the RSA model or the contracting model, or reliance on local governments - based on my experience, I would recommend local governments), the program needs to adhere to the following principles: (1) process transparency and (2) accountability for delivery. On the transparency front, the people, donors, and government must know what is happening on the ground. This information is the foundation for making local governments accountable to the people that they serve. And for keeping local governments honest (reducing the temptation for corruption).

The Government has also to remove implementation and organizational bottlenecks. Creating a Special Implementation Unit (SIU) made up of four "Delivery Tsars" and a high-quality staff (either diaspora or nationals) would be one option. The SIU should be house in the Prime Minister's office to signal that it speaks for the entire government. Three units would cover operational elements (housing and infrastructure, jobs, and vocational training). The PM would task the fourth with ferreting out and remove systemic Government bottlenecks that impede government and private sector actions. As appendages of the PM's office, these units would speak with the government leadership authority.

\section{Convince Donors}

A primary basis for success is that the Timorese government needs to take charge of its development program. Bringing donors on board would have started with a campaign to convince donors that jobs and services delivery were the immediate priorities and that donors must commit to helping deliver on this priority. Next, the PM's office should set Benchmarks that would allow the assessment of the performance of all participants. Benchmarks that would be measurable and therefore monitorable and donors would have made them public to ensure credibility. A governmentproduced and government-owned development strategy designed to clarifies what the Government promises its people and wants from donors would be an essential starting point. The usual donor-driven and donor-produced poverty reduction strategy papers (PRSPs) and UN Development Assistance Frameworks (UNDAFs) are not needed. In terms of specific needs:

1. Terms of reference for nationwide public service delivery

Regardless of the model chosen, the government will need to develop performance measures for its public-service delivery program.

2. Terms of reference for vocational basic skills program

The vocational education program should involve a SouthSouth exchange and should utilize local expertise whenever possible. Creating this exchange requires finding local or regional expertise in construction services (plumbing, electricity, etc.). Then, incentivizing them to teach and mentor others.

3. On housing, seek bids to develop a housing reconstruction program.

The element should look mainly at regional models. While the process must be open, transparent, and competitive, those involved in successful regional housing efforts have the track record Timor-Leste needed.

4. Starting with the Doing Business Survey results, institute a program to fix the country's business environment.

Timor-Leste had already made progress in improving its business environment. The Government had reduced the time needed to start a business. But more needs to be done (for example, the Government could have removed the fees charged for visas). Only bureaucratic inertia stands in the way of a much-improved business environment

\section{Set a tight, challenging schedule}

This initiative must be driven by a sense of urgency, by a need to take risks to get things done in the needed time frame. A standard government or donor program would simply not do.

Most often missing in papers on implementing more effective development programs are the devilish details. That 
is why I have laid out the program for Timor-Leste in detail. While each post-conflict country is different, I am sure that many ideas and even the Timor-Leste program's specifics will ring true in other fragile states. Indeed, this holds for Iraq and Afghanistan, two among my other fragile state experiences.

I do not take on in this essay the incentives problem. Although simple in principle, I understand well that my suggested approach will be difficult for both governments and the donor community. This program would take cooperation, humility, patience, and country ownership, program elements that are sorely missing in the usual donor approach. Plus, governments have grown used to sitting back and having the donor community do everything for them and take responsibility for results.

I know how difficult this can be as I tried to implement a similar approach in Tajikistan when I was the World Bank's country director for Central Asia. I convinced the Bank's Executive Board to take a chance on an unconventional "country strategy" for Tajikistan in which the World Bank would be in a supportive rather than a leadership role. While the World Bank Board was enthusiastic even in the face of the risks involved, Tajikistan's donor community was not enthusiastic.

Even though many of Tajikistan's donor community saw the logic, none were willing to step out of their comfort zones. None were willing to trust others in the donor community to do what they would need to do to make a donor cooperation and specialization system work.

The Tajikistan model failed, but a government-driven model with the same goals could work. Further, what is the alternative? The current system is not working yet getting rid of the current system will not happen. So, we have to find ways to make the current system work.

My experience in Afghanistan dramatically changed the view I held after my time in East Timor.

\section{From EAst Timor to Afghanistan}

At a high cost in terms of treasure and lives, the U.S. has been embroiled in three counterinsurgency wars in the past five decades: Vietnam, Iraq, and Afghanistan. No one would argue that any of these wars ended the way the U.S. wanted. However, the nature of insurgencies provides clues to the reasons for these failures. Since 1964, the world has known that military might alone will not defeat an insurgency [5]. The U.S. knew this fact going into all three of these wars yet continued to act as if its military might alone could do the job: It could not and did not. The following summarizes the arguments I elaborate on in Why Counterinsurgency Fails [3] my Prager and Macmillan book.

\section{A BIT OF BACKGROUND}

Before I launch into the program, the 173rd and I developed a word about me. My military experience began when I was 65. I launched my relationship with the U.S. military as a member of an assessment team assembled by Gen. David Petraeus, which spent an educational month touring Iraq in March 2008. Following that, I was asked to join Petraeus's CENTCOM Assessment Team in Early 2008, and the $173 \mathrm{rd}$ Airborne recruited me in late 2009 to join them in 2010 for their deployment in Afghanistan.

Before I turn to details, a brief primer on Counterinsurgency, David Galula, a French soldierintellectual, is often identified as the father of modern counterinsurgency theory. David Petraeus and James Amos put an up-to-date spin on Galula's work in their 2007 Volume [4]. Galula's and Petraeus's core message is much the same: to defeat insurgencies, we need a combination of military force and a "political" solution.

This formula recognizes that insurgencies arise in states where a "legitimate" Government has failed its citizen by not providing basic services - property rights, transparency, a reasonably fair legal system, some semblance of good governance.

Counterinsurgency's political side requires rebuilding the relationship between a country's people and their government, as does capacity building in international development. To achieve this goal, the coalitions in Iraq and Afghanistan turned to "governance and development" programs to win hearts and minds. The main problem with the approaches taken in these countries was that they were not clear on who needed to be winning hearts and minds outsiders or the country's Government. While the coalitions in these countries may not have been clear on the hearts and minds issue, the literature - and common sense - is.

The "soft" side of a counterinsurgency program needs to help a country's Government rebuild credibility with its people. Unfortunately, in Vietnam, Iraq, and Afghanistan, U.S. action did precisely the opposite. There was so little trust by the U.S. in these countries' governments that the U.S. ended up doing everything - the fighting, development, financial management planning. In other words, the coalition ended up taking over the state's role. The signal to these countries' peoples was that their government was incompetent, not an especially good foundation for rebuilding trust.

What are the constraints to rebuilding trust in a country's Government? By definition, central governments in countries suffering from insurgencies are dysfunctional or, if functional, unpopular. So, where do we start rebuilding people's trust in their government? Based on a model developed in Afghanistan's Lowgar and Wardak provinces, the answer is local Government.

Local governments have several advantages in building a link between people and Government. Most important is that local governments are the face of Government for most people in a country. Second, local authorities know better than any outsider what communities need. Third, because local authorities are usually community members, they tend to be more accountable to their population than is an oftendistant central government, even if appointed rather than elected. The success of the program the 173rd Airborne and I implemented in Afghanistan's Lowgar, and Wardak Provinces in 2010 proved the validity of these assumptions. Sub-governors understood that the People's Development Fund (PDF), as we called it, gave them a chance to show the people they governed that they were worthy of being a subgovernor. Every single sub-governor in the program rose to this challenge.

As mentioned, [3] provides the evidence for this statement. 
Here I summarize the program's main elements and its early outcomes. Starting with the above principles and building on the work others and I had done in Indonesia [15] and Afghanistan [17], the 173rd Airborne and I developed and tested a program that put local Afghan Government Front and Center. The "People's Development Fund" (PDF), named after a much-ignored part of Afghanistan's old budget law, which required the central Government to transfer a fixed proportion of the national budget each year to local governments in the form of a "people's fund."

The PDF was simple in design so that the Afghan Government could scale it up to a national level - no elaborate training program, no direct supervision, relatively affordable. The only role of outsiders was to ensure that participants met transparency requirements. For example, local Governments had to tell their communities how much money a district had received (in the neighborhood of $\$ 100,000)$. Districts decided how to use PDF resources (through a consultative process), which contractors the district hired, what process the district used to hire contractors and the outcomes. These program features for each district were made available to the people of the other districts in a province, which gave each district a basis for judging whether their sub-governor had managed the PDF process and funds well. After the first round of funding, the 173rd gathered all Lowgar and Wardak sub-governors to share experience and train each other. This gathering also underscored that the PDF was their program, not the 173 rd's.

At the end of the first funding round, the 173rd reviewed how each district used its PDF funds. The most striking feature of this review was the diversity of projects funded. In addition, it took minimal digging to understand the reasons behind a district's use of the resources. For example, a highly fractious district chose to allocate its PDF funds more-or-less equally among the competing factions to build trust in the system.

From my experience in Iraq and Afghanistan and my work in other fragile states, I draw these lessons:

- For a successful counterinsurgency campaign, the international community needs to have clarity of mission: are they setting out to create national capacity by giving citizens a sense of their government working for them? Or is their goal to make citizens' lives better as quickly as possible. The tradeoff between these two objectives can be harsh, and any program will have to do some of both. But if the primary objective is to build government capacity, local governments should be the focal point. A program like the Afghanistan People's Development Fund (PDF) developed by the 173rd Airborne and me is an example of such a program that passed its implementation challenges.

- Doing the program means providing only modest money, local responsibility, local accountability, and complete transparency. Lots of money is not the answer-it may well lead to problems rather than solutions. In addition, a program offering smaller amounts of money over a period of years means less rent-seeking and the ability to incentivize actors more easily.

- Donors need a mechanism that lets them work with local governments.

- Donors need to be willing to take risks and accept failure. If they don't, it will be donors, not the government responsible for outcomes. Accepting failure does not imply ignoring incompetence or corruption. Failures that move one up the knowledge and success curve should, however, be acceptable.

\section{Summary AND CONClusions}

This paper's main messages are:

1. Fragile states are a global public good issue on an equal par with climate change.

2. The international community's track record in fragile states demands a rethinking of the current approach.

3. Governments will not build capacity unless donors give them accountability, that is, the right to fail.

4. Local governments are often a far better focal point for development assistance than central governments.

5. Local governments have much greater capacity than they are given credit for and are more accountable to the people they serve and more knowledgeable of their needs than national governments.

\section{ACKNOWLEDGMENT}

The unwavering support for my work in Afghanistan by Col. James Johnson and his 173rd colleagues is gratefully acknowledged, as is the support from East Timor's Ministry of Finance, Especially the Minister of Finance, Emilia Pires, for my work in East Timor.

\section{REFERENCES}

[1] Heider, C., \$13 Trillion and Growing - Addressing the Cost of Fragility and Conflict, Washington DC: World Bank, 2016.

[2] Fragile States, San Francisco: Wikipedia, 2020.

[3] de Tray, D., Why Counterinsurgency Fails: the US in Iraq and Afghanistan, New York: Palgrave and McMillan, 2018.

[4] Petraeus, D. A. The US Army/Marine corps Counterinsurgency Field Manual, Chicago: University of Chicago Press, 2007.

[5] Galula, D., Counterinsurgency Warfare: Theory and Practice. New York: Frederick A. Praeger, 1964.

[6] Radelet S., The Great Surge: The Ascent of the Developing World, New York: Simon \& Schuster paperbacks, 2016.

[7] Kenny, C., Getting Better: Why Global Development Is Succeeding-And How We Can Improve the World Even More, Philadelphia: Basic Books, 2011.

[8] Easterly, W., The White Man's Burden: Why the West's Efforts to Aid the Rest Have Done So Much Ill and So Little Good, Oxford: Oxford University Press, 2006

[9] Moyo, D, Dead Aid, New York: Farrar, Straus, and Giroux, 2009

[10] de Tray, D., Capacity Stripping How the international community contributes to capacity problems in fragile states and what to do about it, Washington DC: Center for Global Development, 2011.

[11] Collier P., Post-Conflict Recovery: How Should Policies be Distinctive, Oxford: Centre for the Study of African Economies, Department of Economics, University of Oxford, 2007.

[12] Svenson J., Absorption capacity and disbursement Constraints, In W. Easterly, Reinventing Foreign Aid, Boston: MIT Press, pp. 311-333, 2008.

[13] Stewart R, The Prince of the Marches, London: Harcort, 2007.

[14] Pritchett, L. A., Solutions When the Solution is the Problem: Arraying the Disarray in Development, Amsterdam: World Development, 2004.

[15] Guggenheim Scott, T. W., Indonesiais Kecamatan Development: A Large-Scale Use of Community Development to reduce poverty, Washington, D.C.: World Bank, 2004.

[16] Collier P., The Bottom Billion: Why the Poorest Countries are Failing and What Can Be Done About I, Oxford: Oxford University Press, 2007.

[17] S. Beath, A. C., The National Solidarity Program, Washington, D.C.: World Bank, 2015. 
[18] Beath, A. F., Randomized impact evaluation of Afghanistan's national solidarity programme, Washington D.C: World Bank, 2013.

[19] Chauvet, L. C., The Cost of Failing States, Helsinki Finland: UNUWIDER, 2007.

[20] Cororan, A. G., Foreign Direct Investment and The Ease of Doing Business, Dublin: School of Economics, University College Dublin, 2012.

[21] Dunne Jean Paul, A. T., Costs of Civil War and Fragile States, Stockholm: School of Economics, SALDRU, 2016.

[22] Galula, D., Counterinsurgency: Theory and Practice, Westport: Prager Security International, 1964.

[23] Green, K., Decentralization and good governance, Munich, Germany: Munich Personal RePEc Archive, 2013.

[24] Hallward-Deiemeier, M. O., How Business is done and the Doing Business Indicators, Washington DC: The World Bank, 2011.

[25] Hofman, B., Decentralizing Indonesia, Washington DC: World Bank, 2003.

[26] IEG the World Bank Group, Village Investment Project and Second Village Investment Project, Washington DC: World Bank Group, 2018.

[27] Jonathan, F., For the People, By the People in Indonesia. Washington DC: Foreign Policy, 2014.

[28] Kirana, G., Decentralization Dilemma in Indonesia: Does. Geneva: School for International Training (SIT), 2014.

[29] Knack, S. A., Donor Fragmentation In W. Easterly, Reinventing Foreign aid. Cambridge: MIT Press, 2008.

[30] Mcmaster, H., Dereliction of Duty, New York: Harper Perennial, 1997.

[31] Nasution, A., Government Decentralization Program in Indonesia, Tokyo: Asia Development Bank, 2016.

[32] Teskey G. A., Tanzania Civil Service Reform Program: Case Study, Harare: Joint DAC Informal Network/ACBF Workshop on Institutional and Capacity Development, 1999.

[33] Decentralization. Washington DC: World Bank, 2013.

[34] Yemak, R. F., Celebrating ten years of the National Solidarity Program (NSP): a glimpse of the rural development story in Afghanistan, Washington DC: World Bank, 2013. 